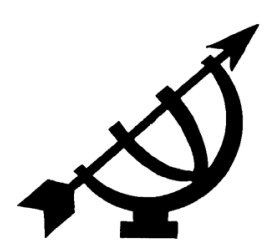

\title{
The role of God in the father/son relationship during identity formation - a Gestalt theoretical perspective
}

\author{
H.B. Grobler \\ Institute for Child, Youth \& Family Studies \\ Huguenot College \\ WELLINGTON \\ and \\ Department of Theology \\ Unisa \\ PRETORIA \\ E-mail: h.awareness@gmail.com
}

\begin{abstract}
The role of God in the father/son relationship during identity formation - a Gestalt theoretical perspective
\end{abstract}

This article is based on research done within the Afrikaansspeaking community in the area of the Drakenstein Municipality, Western Cape province, South Africa. The focus falls specifically on one concept that was outlined during the research, namely the perceptions of fathers and adolescent sons on identity formation within their relationship as well as the role that God plays. Combined qualitative/quantitative research was conducted with emphasis on semi-structured interviews with fathers $(n=4)$ and adolescent boys $(n=4)$ and an auto-ethnography of the author as the dominant component. The lessdominant quantitative component consisted of questionnaires completed by fathers $(n=42)$ and adolescent boys $(n=180)$. Metatheoretical assumptions and theoretical assumptions as grounding for the male identity are discussed as part of the author's paradigmatic perspective. Furthermore, empirical findings are discussed and recommendations are made. From the discussions with fathers and their sons it was clear that both fathers and sons have a need to stand in close relationship to each other and to God. It is within this relationship where their identities are formed. However, fathers seemed to be resistant 
of transferring their beliefs to their sons. Adolescent boys also indicated no need to one day transfer learned behaviour from their fathers to their sons.

\section{Opsomming}

\section{Die rol van God in die vader-/seunverhouding gedurende identiteitsvorming - 'n Gestalt teoretiese perspektief}

Hierdie artikel word gebaseer op navorsing wat gedoen is binne die Afrikaanssprekende gemeenskap in die area van die Drakenstein munisipaliteit, Wes-Kaap provinsie, Suid-Afrika. Die fokus val spesifiek op een konsep wat tydens die navorsing uitgelig is, naamlik die persepsies van vaders en adolessente seuns oor identiteitsvorming binne hulle verhouding, asook die rol wat God speel. Gekombineerde kwalitatiewe/kwantitatiewe navorsing is uitgevoer met die klem op semi-gestruktureerde onderhoude met vaders $(n=4)$ en adolessente seuns $(n=4)$ en ' $n$ outobiografie van die outeur as die dominante komponent. Die minder dominante kwantitatiewe komponent het bestaan uit vraelyste wat voltooi is deur vaders $(n=42)$ en adolessente seuns $(n=180)$. Metateoretiese en teoretiese aannames vir die begronding van manlike identiteit word bespreek as deel van die skrywer se paradigmatiese perspektief. Verder word empiriese bevindings bespreek en aanbevelings gemaak. Vanuit die besprekings met vaders en seuns was dit duidelik dat albei partye 'n behoefte het aan 'n hegte verhouding met mekaar en met God. Dit is binne hierdie verhouding waar hulle identiteit gevorm word. Dit blyk egter dat vaders 'n weerstandigheid toon om hulle geloofsoortuigings aan hulle seuns oor te dra. Adolessente seuns het ook aangedui dat hulle geen behoefte het om gedrag wat hulle van hulle vaders geleer het eendag aan hulle seuns oor te dra nie.

\section{Introduction}

This article was written within the context of the current South African society that is characterised by relational diversity such as constant debates about male identity and homosexuality (cf. Nicolosi, 2004), family violence where fathers often initiate family murders (cf. SAPS, 2005) and a unique patriarchal composition. This composition is often linked to Calvinism and the African male as well as the uniqueness of the role that the father portrays within his family (cf. studies of Stevens in Lindegger, 2006:129). Increased awareness concerning the role of the father in the identity formation of his son exists (Prinsloo, 2006). The importance of the role of fathers regarding the identity formation of their sons cannot be disputed and has been confirmed by numerous researchers and theorists 
(cf. Gorski, 1998; Wade, 1998; Thomas, 2005; Richter \& Smith, 2006; Pleck, 2007). According to the author, male identity can be seen as the main binding factor in the relationship between father and son. It is within this relationship between father and son where both need to work through inner and interpersonal conflict. The quality of involvement of the father with his son is of extreme importance, thus leading to identity formation and awareness. From his perspective the author sees true identity as solely obtainable for father and son when their own identity is rooted in that of God.

The focus of this article falls on three aspects, namely meta-theoretical assumptions, theoretical assumptions and research methodology for the grounding of male identity as a methodological process and the role it plays as the main binding factor in the relationship between father and son.

\section{Problem formulation}

In the same way that identity transference takes place from father to son through communication and example, identity confusion also takes place, as other role models in the son's life may be lacking or he may not have the necessary skills to assimilate other role models' positive identity formation (Grobler, 2007:10). The author has been confronted with the occurrence of poor father/son relationships through his work as play therapist as well as through his personal experience of a poor relationship with his own father. However, the author also experienced the power of God as complementary to his relationship with his father.

Not much has been done within the South African context regarding the provision of answers to fathers on how to guide their sons towards a stable relationship in which both father and son can express their identity as men (Grobler, 2007:6). Mandara et al. (2005:218) refer to specific studies with African-American adolescents and have come to the conclusion that "father absence and family income are related to gender role development in both male and female". In another study Pleck (2007:197) states that existing research becomes increasingly aware of the possible influences of fathers' involvement on their children. However, the mere fact that the father is involved as caregiver does not necessarily simplify the complexity of the father/son relationship. A classic example of the complexity of a father/son relationship can be found in the Greek mythology where Oedipus murders his own father. The Bible story of Abraham and his son Isaac (Gen. 22) stands as another example of the dynamic and complex relationships between fathers and sons, where the father's 
loyalty and love for God as well as for his son, Isaac, is emphasised. Often stories of the relationship between father and son are based on the consequences of friction between father and son or specifically on the disobedient son who does not want to accept the authority of the father. One such an example is the parable of the prodigal son as described in Luke 15:11-31.

The problem that can be stated is that the formation of male identity within the father/son relationship becomes more complicated without God's presence standing in the centre. Fathers and sons find it difficult to communicate. Fathers' actions may not always coincide with their verbalised beliefs, which may bring about resistance among their sons and have consequences for the transference of information important for identity formation.

\section{Objective of article}

In this article the author discusses the relationship between father and son and how the son's identity formation relies on this relationship as well as the specific involvement of the father. The importance of the way in which the father manages this relationship and according to how the father can guide his son towards a male identity that can provide the son with structure for maturation, is emphasised. This discussion is done from a Gestalt meta-theoretical perspective. The author also looks at the father/son relationship from a Christian perspective with a belief in the triune God. However, God as the Father stands central in this discussion, as the author believes that it is in his example of being the perfect Father that freedom lies. It is the author's subjective experience of God that colours his paradigm and thus the way he thinks the father/son relationship should be approached. This subjective view of the experience of God is also explained by Louw (1997:72) when he writes that the way in which God is portrayed is a complex matter and that no pure portrayal exists in which God can be introduced as fully comprehensible.

\section{Metatheoretical assumptions}

The metatheoretical assumptions of the Gestalt theoretical perspective, form part of the author's paradigm and his approach to the article and life in general. The author's perspective on the father/son relationship is further enhanced by the Gestalt phenomenology (Joyce \& Sills, 2001) where the emphasis is on awareness, dialogue and process (Yontef, 1993). 


\subsection{The organism defines itself by meeting the other at the contact boundary}

Fathers and sons develop relationships with the people around them. Within these relationships they have a need for awareness, dialogue and process in order to maintain balance (equilibrium) in terms of their identity. The importance of these relationships between the self and others is emphasised by Yontef (1993:136) where he states that "a person exists by differentiating self from other and by connecting self and other". This contact-making process is crucial within the father/son relationship. According to the author this meeting place (contact-making process) can only be authentic when both father and son are true to who they are and when they do not try to manipulate the other person in becoming someone he is not.

The paradoxical theory of change described by Beisser (quoted in Yontef, 2007:17) explains this concept by stating that: "[p]eople do not change by trying to be who they are not". As soon as the father meets the son with a "false self" a basis for healthy identity formation cannot be established. This awareness of self can only be achieved when a person becomes who he truly is and not when he tries to become someone he is not (Joyce \& Sills, 2001:37; Polster, 2005:78) by accepting introjects without assimilation. The importance of a unique and personal relationship not only between father and son, but also between man and God is discussed by Louw (1997:77) when he describes this relationship in terms of metaphors. According to Louw the relationship between man and God should be of such quality that optimal joy in existence is experienced and that hope is formed. He chooses the friend metaphor to describe this experience and that concurs with the author's viewpoint that the relationship with God should be personal and intimate. This relationship exists through contact at the boundary between God and the father and God and the son.

\subsection{Awareness and awareness continuum}

The awareness continuum within which father and son function takes place in the here and now and is experienced as an experiment that continuously makes them aware of themselves and of their relationship with God and creation. It is within this relationship in the here and now that the child engages in dialogue with the adult. The adult becomes aware of his unfinished business, which is the first step towards identity formation. Although no father is perfect, he needs to become aware of his own unfinished 
business and to address it in order not to project his own hurt onto his son in a way that may influence his son's sense of self and identity formation. Joyce and Sills (2001:28) emphasise the importance of awareness by saying that "it is the ongoing experience of awareness that can be enormously healing ...". Goldstein (qouted in Votsmeier, 1996) also refers to awareness of the self that indicates optimal awareness of a person's specific nature, i.e. that which he can achieve in order to cope with the world. It is within this awareness that connection, spontaneity and freedom are found (Joyce \& Sills, 2001:27).

\subsection{The phenomenological field in which awareness and dialogue occur}

Identity occurs in relation to the environment (field). The field forms part of the individual (organism) which is seen as a whole (gestalt). The identity of both the father and son can thus not exist without their contact with the other and with the broader field (for example family, friends, people in the work environment and peers at school). Within the field it is important for the person "to neither isolate him artificially, nor to 'merge' in the global field" (Ginger, 2007:109). Fields that play important roles regarding awareness and dialogue may include the peer group, family and other environmental influences.

\subsubsection{The peer group as part of the field}

The peer group plays an important role during adolescence (Berk, 2003:601; Louw \& Edwards, 2003:489) and consequently during identity formation. It is important for the father to acknowledge his son's process of identity formation. The role of the father should also not be underestimated. According to Richter (quoted in Louw \& Louw, 2007:135) fathers represent "one of the most important ... resources for children's well-being". Louw and Louw (2007:326) continue by saying that conflict with the adolescent does not necessarily influence the relationship with parents negatively and is sometimes even necessary for personal growth.

\subsubsection{The family as field}

Berk (2003:602) emphasises the importance of identity formation at home, as parents can influence the social relationships of their children by providing guidance regarding behaviour towards others. According to Kindermann (2003:415) parents may have certain expectations regarding their children's development and may see their 
role as a determining factor in this process of development. Louw (1997:72) mentions the importance of the way in which God is perceived and the influence this perception may have on family systems. He states that the experience of faith results in certain perceptions of God in which influences like the family system play a significant role. Louw continues by saying that parents serve as role models who act as representatives of God to their children. This representation plays an important function in how God is perceived.

\subsubsection{Other external environmental influences as part of the field}

Other external environmental influences on identity are identified by Berk (2003:460) as personality, school and society as well as the broader community, for example the wider cultural context and the historical time period that affects identity development. According to the author the adolescent boy will be challenged within his broader field and needs to find his security within his relationship with God in order to take a stand in the outside world. Without this security he may develop a false identity that can be based on expectations of others and not on the truth that can only be found in Jesus Christ.

\subsection{Process}

\subsubsection{Components of identity as part of the process}

Although identity can be referred to as global (Kaplan, 2000:514), it also consists of various components which are dynamic and interdependent, namely personal, religious, vocational, interpersonal, moral, gender and ethnic identity (Berk, 2003; Louw \& Edwards, 2003; Thomas, 2005). Each individual is distinguished from others by his/her unique process, including attributes like physical and personal characteristics, date of birth, intelligence, name, attitude, needs and interests. Certain aspects of identity stay the same, while others may change over time (Bosma \& Gerlsma, 2003:451). Identity can further be seen as the awareness of who you are at that specific point in time in relation to your field (Joyce \& Sills, 2001:86), for example friends, family, experiences, emotion and your relationship with God.

\subsubsection{Identity confusion as part of the process}

Identity confusion can occur in any developmental phase, but critical periods of confusion are experienced from adolescence and onwards. Identity confusion can be triggered by a person's personal boundaries or contact-making functions - how he/she interacts with 
his/her environment. Gestalt theory refers to contact boundary disturbances when these contact functions influence the person's functioning negatively. Yontef (1993:137) refers to these contact boundary disturbances as "a disturbance of the distinction between self and others, a disturbance of both contact and awareness", and links it directly to the boundary between self and others that "becomes unclear, lost or impermeable". Introjection is one such disturbance that occurs when foreign ideas are absorbed without discrimination (Perls, 1992:152). Identity, for example, can be transferred as an introject from father to son without the son being able to assimilate and make it his own.

\section{Theoretical assumptions of study}

A variety of theoretical models constitute the theoretical assumptions that have been used for the purpose of this article. However, Gestalt therapy theory forms the core assumption. Although there are many factors that play a role in identity formation, the focus for this article is on the relationship between father, son and God, and the specific consequences of this relationship for identity formation/ identity confusion. The author finds this relationship of such importance that it is related to many factors that determine identity. Components of the following theoretical models were used and are only briefly mentioned. The author chose these models because of their focus on the father/son relationship and their emphasis on the importance of father involvement in identity formation of children:

\subsection{Psychoanalytic approach}

According to Minsky (2005) psychoanalytic perspectives suggest that fathers who are not violent or do not have tendencies towards sexual, emotional and physical abuse, have a central position regarding the subconscious emotional development of identity. Fathers' roles differ from those of mothers and are viewed as irreplaceable where the development of childrens' identity is concerned. The emotional and physical absence of fathers is often the reason for adults having a need for psychotherapy. According to Freud the early identification of the child with the father establishes a certain culture that stands central to his/her being (cf. Minsky, 2005; Gorski, 1998).

\subsection{The role theory}

This theory indicates that all behaviour is determined by social prescriptive roles (Gorski, 1998). Men, for example, take up masculine 
roles that are prescribed by society. As they learn to own these roles, their male identity is formed.

\subsection{Social relationships perspective}

According to Edley and Wetherell (quoted in Gorski, 1998) this perspective indicates that identity emerges from men's positioning within a variety of social structures. Tolson (quoted in Gorski, 1998) is of the opinion that the foundation for the development of male identity is laid during the childhood years. According to him family has the first cultural and emotional influence on boys. Within families boys develop the need to prove themselves, which is also reinforced by schools and peer groups. In these institutions identity messages like "boys don't cry" and "boys will be boys" are sent out. Boys are pressurised to achieve what their fathers had achieved. Fathers' identities on the other hand are also formed by their workplace. The father learns that he has to work through certain structures to survive and the behaviour he has to adapt to survive is defined as so-called masculine behaviour.

\subsection{Identity theory}

Originating in the works of George Herbert Mead the focus is on "society shapes self, [self] shapes social behaviour" (Stryker \& Burke, 2000). The self consists of many facets which in turn consist of interdependent and dependent parts that empower and contradict each other reciprocally.

\subsection{Developmental perspective}

During the grounding of identity it became clear to the author that identity develops hand in hand with developmental dynamics. Special preference is given to the psychosocial theory of development of Erik Erikson (Berk, 2003:18). Phase five of Erikson's theory, identity versus identity confusion, was especially of interest to the author, because it focuses on the adolescent. It is during adolescence that the boy develops an idea of who he is and where he belongs.

\subsection{The dynamics of identity formation}

Marcia (quoted in Kaplan, 2000:514) describes the process of identity formation by using four categories or statuses. Adolescents are then described accordingly in terms of their experience with crises as well as their ability to commit themselves. Berk (2003:457) also describes identity status as being related to specific attitudes and 
behaviour. The adolescent that reaches the last phase develops an identity that contains certain values and attitudes of his parents, while others are excluded. This phase coincides with Perls's assimilation phase of introjects. In this phase the adolescent is welladapted and has good relationships with his/her peer group as well as with authoritative figures.

\section{Research method}

The research approach applied in this article is based on a combined dominant-less-dominant approach with qualitative research as the dominant leg. The qualitative research consisted of a case study (Fouché, 2005:272; Nieuwenhuis, 2007:75) as strategy, semi-structured interviews with adolescent boys and fathers of adolescent boys as well as an auto-ethnography. The quantitative research consisted of a multi group post-test-only design (Fouché \& De Vos, 2005:136) in the form of questionnaires. According to Neuman (2003:139) qualitative and quantitative research may differ significantly, but also compliment each other. Applied research was conducted with an explorative and descriptive nature. Neuman (2003: 22) states that applied research focuses on a specific aspect or provides solutions for a problem. Applied research is mostly used with a relatively small study that provides practical solutions and that can be used within a short period of time. This aspect made applied research ideal for this study where the focus was on identity of adolescent boys and fathers of adolescent boys for whom a guiding framework was compiled. The study was conducted in the area of the Drakenstein municipality, Western Cape province, over a short period of time and practical guidelines were provided. From the qualitative data categories were identified and applied as indicators within the questionnaires. After data were analysed the content of both qualitative data and quantitative data was integrated in the form of six concepts. Literature control was done after which the concepts were integrated and presented as a guiding framework. The fifth concept, namely the role and place of God in identity formation of fathers and adolescent sons, forms the focus of this article.

Non-probability sampling was done, because of the qualitative nature of the study that formed the dominant leg of the research. Purposive sampling (Maree \& Pietersen, 2007:178) was chosen, because the respondents had to meet specific criteria (cf. Neuman, 2003:213.) The specific size of the sample regarding the qualitative component was not determined beforehand, because the respondents merely had to comply to the sampling criteria (cf. Neuman, 
2003:211). Interviews were held until saturation was met. Indicators that were identified during the interviews were used to compile questions for the questionnaire. These questions had to comply with criteria validity and content validity as suggested by Bostwich and Kyte (quoted in Delport, 2005:160-162).

\section{Findings of research}

\subsection{Qualitative research, semi-structured interviews and auto- ethnography}

From the data gathered during the semi-structured interviews and auto-ethnography, six concepts were identified as important for fathers and their sons regarding identity formation within the father/ son relationship. It was clear that God plays a role within the identity formation of adolescent boys and their fathers. This was evident in the fifth concept, namely the role and place of God in identity formation of fathers and sons. This concept refers to the opinions of respondents regarding the role of God and his place in identity formation. Three categories came to the fore under this concept, namely the practising of Christianity, values and norms and renewal through the Holy Spirit. With reference to the practicing of Christianity it was evident that God and the experience of God served as anchor for the respondents regarding their experience of themselves. One respondent stated the following:

[M]y identity is part of who I am as Christian. These two aspects cannot be separated. In God lies identity. Christianity is to walk a road with God. Forwards. It is rejecting that which is not of God, finding out what God really wants and not to merely keep to dogma that was taught to me as child. It is a relationship that is more than most people think and within this relationship lies my identity.

Another respondent stated that

... because I am a Christian, I do Bible study every evening and I feel guilty when I do not do it. I will think before I do something and wonder what Jesus would do.

By clinging to faith the humanity of the respondents is anchored.

The practicing of values and norms is closely connected to the responsibility that the fathers experienced regarding their roles as heads of families and as fathers to their sons. Values and norms and the experience thereof can be found in the practicing of 
Christian principles. Mere conformity with regard to values and norms was not an option and there was a need for depth regarding Christianity, a need to really believe in God, also in the self. One of the respondents stated that norms are a good recipe book that you need to follow cognitively. Another respondent found it important to be in church every Sunday and to pray with his family every day. It was important for a respondent to teach his children respect for maintaining their Christian values.

Regarding the third category the perception exists that faith and a relationship with God serve as security for the fathers in their behaviour towards their sons. One respondent stated that "God reminds me of my redemption and renewal takes place. My initiative and trust empowers me to fulfil His will". Another respondent reacted by saying that the Holy Spirit renews him and enables him to think differently about his son, about their relationship and about what he as father has to do. Renewal and confirmation of faith provides security to fathers about choices they have to make as fathers. One of the respondents sometimes still experienced his old self as strong and that could make it difficult for him as father.

\subsection{Quantitative research, questionnaires}

The role and place of God in identity formation with fathers and sons are characterised by aspects such as the ways in which fathers and sons experience Christianity and the experience of Christian values and norms in faith that serve as guidelines for fathers who are unsure about their own identity and need to guide their children.

Faith in God is seen as an inseparable part of the fathers' male identity and the practice thereof supports their male identity. The number of fathers who were of the opinion that God has an influence on their male identity was 32, whereas 149 adolescents indicated that God has the biggest influence among all other aspects on their identity formation. Male identity is set within the male person's faith in God and makes the transference of this faith from generation to generation an important component of identity formation. Faith in God also forms a central part of the adolescent boy's male identity and provides a platform for forming male identity through the practice of his Christian faith. However, although God and the practising of Christianity are of importance to adolescent boys, only twelve of them would like to transfer that which they have learned from their fathers regarding the practicing of Christianity to their own children. Only six adolescent boys indicated that their identity is influenced by the way in which their fathers lived their Christianity. 
Similarly only four fathers viewed the way in which their fathers practiced their Christianity as having an influence on their identity. Only seven fathers had the need to transfer faith as a component of identity to their sons. It thus seemed that although the fathers verbalised the importance of God and the practicing of Christianity regarding identity formation, they failed to transfer this viewpoint to their sons.

Values and norms play an important role in identity formation - for both fathers and sons. However, only nine fathers indicated that they have transferred values and norms, learned from their own fathers, to their sons. These values and norms have also been taken from their own fathers, to be transferred to their sons. The significance of values and norms in the transference of identity from generation to generation does not seem to be important to adolescent boys, as only 23 indicated that they would like to transfer learned values and norms from their fathers to their sons. It thus seems that although values and norms form an integral part of the respondents' male identity, they did not value their own fathers' values and norms as important enough for transference to their sons. A similar outcome was received from the fathers.

\section{Summary and recommendations}

The adolescent boys as well as the fathers of adolescent boys, link their male identities to their relationships with God. These relationships with God are experienced by the fathers as a renewal of their identity. The relationships of the fathers and sons with God serve as basis for security upon which they can fall back in terms of who they really are. However, the possibility exists that faith can be transferred as an introject from generation to generation without owning taking place. This was evident in the results where fathers and sons indicated that their identity formation is not influenced by the way in which their fathers lived their Christianity. Although they grew up with specific faith-based values and norms as portrayed by their fathers, they did not necessarily value them in the same way their fathers did.

It is the opinion of the author that, without his relationship with God, the father is unable to assimilate his own true identity. This leads to an unbalance (disequilibrium) within himself and within his relationship with his son which in turn can lead to unreasonable expectations and friction within the father/son relationship. Both father and son thus need to find their true identity within God, which will enable them to meet each other at the boundary in an authentic way. 
The adolescent's identity lies within the process of externalisation where he finds himself in a process of questioning, discovering and experimentation. Embedded values are questioned and new values are experimented with. However, identity can also be accepted without questioning. An adolescent, for example, may accept the values of his father without developing his own or he may conform to the peer group without questioning their behaviour.

The father/son relationship serves as the perfect example of true identity. It is within this relationship with God where the father of the adolescent boy can act as a role model to guide his son to his own identity and masculinity. An intimate relationship between father and son (within the covering relationship with God) is, according to the author, the most important aspect in identity formation within the adolescent boy. If the father has not assimilated his own father's example as male role model, the transference of male identity to his own son would probably not be a natural process. He will have to find his own identity in his relationship with God in order to be able to have an intimate relationship with his son.

The individual relationships of both father and son with God can be experienced by them as a renewal of their identity. The relationships of the fathers and sons with God serve as a basis for security upon which they can fall back in terms of who they really are. However, the possibility exists that faith can be transferred as an introject from generation to generation without owning taking place. If faith in God is accepted as an introject, it forms the basis of a false identity. Fathers and sons should therefore examine their relationship with God and not merely believe because their fathers believed. The male identity of fathers and sons is determined by their active practicing of the Christian faith. If Christianity is not lived to the full, feelings of guilt can develop, especially in the adolescent boy, as a certain discourse regarding the practicing of faith in God can exist in the community in which the father and son find themselves. These feelings of guilt can also be caused by values and norms that are transferred as introjects from generation to generation.

\section{Conclusion}

The father/son relationship plays an important role in identity formation in both the father and the son. Covering this relationship is the unique relationship that both father and son have with God. Identity formation is a continuous process, but true identity can only be found within the father/son relationship. Identity is transferred from one generation to the next, but each individual has to find his own 
unique identity by assimilating what has been learnt from his father. The practicing of Christianity, values and norms as well as renewal through the Holy Spirit are aspects that form an important part of identity formation. Faith in God provides a platform for both father and son to find their true identity. Viewing the world from a Gestalt theoretical perspective, the author finds the above discussion to be valuable and a confirmation of the importance of the relationship between organisms; between the self and the other; between God and father/adolescent. The author is of the opinion that only by being true to the authentic self, the father and son can stand in a relationship in which healthy identity formation can occur. The author suggests a framework for identity formation with Gestalt therapy theory and a personal relationship with God as the foundation.

\section{List of references}

BERK, L.E. 2003. Child development. 6th ed. Boston: Pearson Education.

BOSMA, H. \& GERLSMA, C. 2003. From early attachment relations to the adolescent and adult organization of self. (In Valsiner, J. \& Connolly, K. Handbook of developmental psychology. London: Sage. p. 450-488.)

DELPORT, C.S.L. 2005. Quantitative data collection methods. (In De Vos, A.S., Strydom, H., Fouché, C.B. \& Delport, C.S.L. Research at grass roots for the Social Sciences and human service professions. 3rd ed. Pretoria: Van Schaik. p. 159-191.)

FOUCHÉ, C.B. 2005. Qualitative research designs. (In De Vos, A.S., Strydom, H., Fouché, C.B. \& Delport, C.S.L. Research at grass roots for the Social Sciences and human service professions. 3rd ed. Pretoria: Van Schaik. p. 267-273.)

FOUCHÉ, C.B \& DE VOS, A.S. 2005. Quantitative research designs. (In De Vos, A.S. Strydom, H., Fouché, C.B. \& Delport, C.S.L. Research at grass roots for the Social Sciences and human service professions. 3rd ed. Pretoria: Van Schaik. p. 132-143.)

GINGER, S. 2007. Gestalt therapy: the art of contact. London: Karnac.

GORSKI, P. 1998. Racial and gender identity development in white male multicultural educators and facilitators: toward individual processes of selfdevelopment. file://E:IPaul\%20Gorski\%20-\%20Dissertation\%20-\%20 Review\% 20of\% 20the\%20Literature Date of access: 6 Sept. 2006.

GROBLER, H.B. 2007. Manlike identiteit: 'n begeleidingsraamwerk vir vaders en hul seuns. Pretoria: Universiteit van Suid-Afrika. (Doktorale proefskrif.)

JOYCE, P. \& SILLS, C. 2001. Skills in Gestalt counselling \& psychotherapy. London: Sage.

KAPLAN, P.S. 2000. A child's odyssey: child and adolescent development. Belmont: Wadsworth.

KINDERMANN, T. 2003. Children's relationships and development of personcontext relations. (In Valsiner, J. \& Connolly, K. Handbook of developmental psychology. London: Sage. p. 407-430.) 
LINDEGGER, G. 2006. The father in the mind. (In Richter, L. \& Morrell, R. BABA: Men and fatherhood in South Africa. Cape Town: HSRC. p. 121131.)

LOUW, D.A \& EDWARDS, D.J.A. 2003. Sielkunde: 'n inleiding vir studente in Suider-Afrika. 2e dr. Johannesburg: Heinemann.

LOUW, D.A. \& LOUW, A. 2007. Child and adolescent development. Bloemfontein: ABC.

LOUW, D.J. 1997. Die rol van Godsbeelde/voorstellinge in die ontwikkeling van lidmate se geloof - 'n pastoraal-diagnostiese model. Praktiese teologie in Suid-Afrika, 12(1):64-79.

MANDARA, J., MURRAY, C.B. \& JOYNER, T.N. 2005. The impact of fathers' absence on African American adolescents' gender role development. Sex roles, 53(3 \& 4):207-220.

MAREE, K. \& PIETERSEN, J. 2007. Sampling. (In Maree, K., ed. First steps in research. Pretoria: Van Schaik. p. 172-181.)

MINSKY, R. 2005. Beyond nurture: finding the words for male identity. http://human-nature.com/free-associations/minskynurture.html. Date of access: 27 Sept. 2006.

NEUMAN, W.L. 2003. Social research methods. 5th ed. Boston: Allyn \& Bacon.

NICOLOSI, J. 2004. Fathers of male homosexuals: a collective clinical profile. file://E:IFathers\%20of\%20Male\%20Homosexuals $\% 20$ A $\% 20$ Collective $\% 20$ Clinical\%20Profile Date of access: 6 Sept. 2006.

NIEUWENHUIS, J. 2007. Qualitative research designs and data gathering techniques. (In Maree, K., ed. First steps in research. Pretoria: Van Schaik. p. 70-97.)

PERLS, F.S. 1992. Ego hunger and aggression. New York: Gestalt Journal.

PLECK, J.H. 2007. Why could father involvement benefit children? Theoretical perspectives. Applied development science, 11(4):196-202.

POLSTER, E. 2005. A population of selves. Gouldsboro: Gestalt Journal.

PRINSLOO, J. 2006. Where have all the fathers gone? Media (ted) representations of fatherhood. (In Richter, L. \& Morrell, R. BABA: men and fatherhood in South Africa. Cape Town: HSRC. p. 132-146.)

RICHTER, L. \& SMITH, W. 2006. Children's views of fathers. (In Richter, L. \& Morrell, R. BABA: men and fatherhood in South Africa. Cape Town:

\section{SAPS} HSRC. p. 155-172.)

\section{see SOUTH AFRICAN POLICE SERVICE}

SOUTH AFRICAN POLICE SERVICE. 2005. Year report: crime statistics. Pretoria: State Press.

STRYKER, S. \& BURKE, P.J. 2000. The past, present and future of an identity theory. IIBurkepldIPapers/MillenniumlIdentityTheory5f.doc Date of access: 6 Sept. 2006.

THOMAS, R.M. 2005. Comparing theories of child development. 6th ed. California: Wadsworth.

VOTSMEIER, A. 1996. Kurt Goldstein and holism. Lecture held at the GTILASummer-Residential-Program, Barcelona.

WADE, J.C. 1998. Male reference group identity dependence. file://E:/ Male\%20Reference\%20Group\%20Identity\%20Dependence\%20A\%20The ory\%20 Date of access: 6 Sept. 2006.

YONTEF, G.M. 1993. Awareness, dialogue and process. Highland: Gestalt Journal. 
YONTEF, G.M. 2007. The power of the immediate moment in Gestalt therapy. Contemporary psychotherapy, 37:17-23.

\section{Key concepts:}

father/son relationship

Gestalt therapy theory

identity formation

religion

self, sense of

Kernbegrippe:

Gestalt terapie teorie identiteitsvorming

religie

self, gewaarwording van

vader-/seunverhouding 
